${ }^{\circ}$ Н. О. Гевкалюк

ДВНЗ «Тернопільсъкий державний медичний університет ілені І. Я. Горбачевсъкого МОЗ України»

\title{
КЛІНІЧНА ОЦІНКА ЕФЕКТИВНОСТІ ЗАСТОСУВАННЯ ФІТОПРЕПАРАТІВ СОЛОДКИ КОРЕНЯ ТА ЕЛЕКАСОЛУ В КОМПЛЕКСНІЙ ТЕРАПІЇ УРАЖЕНЬ ПОРОЖНИНИ РОТА У ДІТЕЙ ПРИ ГРИПІ Й ІНШИХ ГОСТРИХ РЕСПІРАТОРНИХ ВІРУСНИХ ІНФЕКЦІЯХ
}

Мета дослідження - оптимізувати схему пікування місцевих проявів захворювання на слизовій оболонці порожнини рота в комплексній терапії хворих на гострі респіраторні вірусні інфекції дітей шляхом використання фрітопрепаратів солодки кореня та елекасолу.

Матеріали та методи. Проведено клінічне дослідження та лікування 318 дітей, хворих на гострі респіраторні вірусні інсекції, з проявами захворювання в порожнині рота. Спостережуваних хворих було поділено на 2 групи: перша включала 127 дітей, у комплексній терапії яких використовували фрітопрепарати солодки кореня та елекасолу для загального та місцевого лікування, друга - 132 пацієнтів, які отримували стандартне лікування. Ефективність проведеного лікування підтверджувалась лабораторними дослідженнями.

Результати дослідження та їх обговорення. У пацієнтів, які в комплексному лікуванні отримували фрітопрепарати солодки кореня та елекасолу, відмічали тенденцію до зменшення загальноінтоксикаційного синдрому, скорочення температурної реакції, тривалості кашлю. Виражена гіперемія слизової оболонки порожнини рота зникала при запропонованому методі лікування на $(2,06 \pm 0,05)$ дня раніше, ніж при традиційному. Тривалість катарального гінгівіту скоротилась $3(11,01 \pm 0,03)$ до $(9,21 \pm 0,01)$ дня, зерниста енантема змінювалась ін'єкцією судин упродовж $(2,06+0,05)$ дня в дітей основної групи та $(3,12 \pm 0,08)$ дня в дітей групи порівняння. Зменшення інтенсивності посиленого судинного рисунка спостерігали протягом $(7,68 \pm 0,02)$ та $(8,06 \pm 0,04)$ дня, а геморагічних плям - $(7,21 \pm 0,01)$ і $(7,68 \pm 0,02)$ дня в дітей основної та групи порівняння відповідно. Ерозії на слизовій оболонці порожнини рота епітелізувались при запропонованій схемі лікування на $(2,89 \pm$ $0,01)$ дня раніше, тривалість періоду епітелізації вогнищ десквамації епітелію язика становила $(10,68 \pm 0,04)$ дня (у групі порівняння - $(12,99 \pm 0,01)$ дня). Інтенсивність больового синдрому зменшилась у $24,41 \%$ хворих. Встановлено регресію ознак гострого вірусного сіаладеніту (в середньому на $(2,32 \pm 0,01)$ дня менше, ніж у хворих групи порівняння). Тривалість регіонарного лімфраденіту скоротилась на $(2,10 \pm 0,01)$ дня і становила $(11,11 \pm 0,03)$ дня.

Висновок. Моніторинг ефеетивності використання фрітопрепаратів солодки кореня та елекасолу в комплексному лікуванні дітей, хворих на гострі респіраторні вірусні інфекції, з проявами захворювання в порожнині рота показав, що застосування відвару солодки кореня й елекасолу всередину і місцеве використання препаратів у вигляді орошень та аплікацій сприяють скороченню тривалості захворювання.

Ключові слова: гострі респіраторні вірусні інфекції; ураження порожнини рота; фрітопрепарати солодки кореня та елекасолу; діти.

КЛИНИЧЕСКАЯ ОЦЕНКА ЭФФЕКТИВНОСТИ ПРИМЕНЕНИЯ ФИТОПРЕПАРАТОВ СОЛОДКИ КОРНЯ И ЭЛЕКАСОЛА В КОМПЛЕКСНОЙ ТЕРАПИИ ПОРАЖЕНИЙ ПОЛОСТИ РТА У ДЕТЕЙ ПРИ ГРИППЕ И ДРУГИХ ОСТРЫХ РЕСПИРАТОРНЫХ ВИРУСНЫХ ИНФЕКЦИЯХ

Цель исследования - оптимизировать схему лечения местных проявлений заболевания на слизистой оболочке полости рта в комплексной терапии больных острыми респираторными вирусными инфекциями детей путем использования фритопрепаратов солодки корня и элекасола.

Материалы и методы. Проведено клиническое исследование и лечение 318 детей, больных острыми респираторными вирусными инфекциями, с проявлениями заболевания в полости рта. Наблюдаемые больные были поделены на 2 группы: первая включала 127 детей, в комплексной терапии которых использовали фритопрепараты солодки корня и элекасола для общего и местного лечения, вторая - 132 пациентов, которые получали стандартное лечение. Эффективность проведенного лечения подтверждалась лабораторными исследованиями.

Результаты исследования и их обсуждение. У пациентов, которые в комплексном лечении получали сритопрепараты солодки корня и элекасола, отмечали тенденцию к уменьшению общеинтоксикационного синдрома, укорочение температурной реакции, длительности кашля. Выраженная гиперемия слизистой оболочки полости рта исчезала при предложенном методе лечения на $(2,06 \pm 0,05)$ дня раньше, чем при традиционном. Длительность катарального гингивита сократилась с $(11,01 \pm 0,03)$ до $(9,21 \pm 0,01)$ дня, зернистая энантема сменялась инъекцией сосудов на протяжении $(2,06 \pm 0,05)$ дня у детей основной группы и $(3,12 \pm 0,08)$ дня у детей группы сравнения. Уменьшение интенсивности усиленного сосудистого рисунка наблюдали на протяжении $(7,68 \pm 0,02)$ и $(8,06 \pm 0,04)$ дня, а геморрагических пятен - $(7,21 \pm 0,01)$ и $(7,68 \pm 0,02)$ дня у детей основной и группы сравнения соответственно. Эрозии на слизистой оболочке полости рта эпителизировались при предложенной схеме лечения на $(2,89 \pm 0,01)$ дня раньше, длительность периода эпителизации очагов десквамации эпителия языка составляла $(10,68 \pm 0,04)$ дня (в группе сравнения - $(12,99 \pm 0,01)$ дня). Интенсивность болевого синдрома уменьшилась у $24,41 \%$ больных. Установлено регрессию признаков острого вирусного сиаладенита (в среднем на $(2,32 \pm 0,01)$ дня меньше, чем у больных группы сравнения). Длительность регионарного лимфаденита сократилась на $(2,10 \pm 0,01)$ дня и составила $(11,11 \pm 0,03)$ дня. 


\section{Педіатрія}

Вывод. Мониторинг эфффективности использования фритопрепаратов солодки корня и элекасола в комплексном лечении больных острыми респираторными вирусными инфекциями детей с проявлениями заболевания в полости рта показал, что применение отвара солодки корня и элекасола внутрь и местное использование препаратов в виде орошений и аппликаций способствуют сокращению длительности заболевания.

Ключевые слова: острые респираторные вирусные инфекции; поражения полости рта; фитопрепараты солодки корня и элекасола; дети.

CLINICAL EVALUATION OF THE EFFICACY OF HERBAL LICORICE ROOT AND ELECASOLUM IN THE TREATMENT OF ORAL LESIONS IN CHILDREN WITH INFLUENZA AND OTHER ACUTE RESPIRATORY VIRAL INFECTIONS

The aim of the study - to optimize the treatment plan of local manifestations of the disease in oral cavity mucous membrane in complex therapy of children with acute respiratory viral infections with the use of herbal medicinal products of licorice root and elecasolum.

Materials and Methods. A clinical trial and treatment of 318 children with acute respiratory infections with manifestations of the disease in the oral cavity was conducted. Observed patients were divided into 2 groups: the first included 127 children, in the complex treatment of which we used licorice root herbal medicinal product and elecasolum for general and local treatment, the second - 132 patients received standard treatment. The efficiancy of the treatment was confirmed by laboratory tests.

Results and Discussion. In patients who received herbal medicinal product liquorice and elecasolum in a complex treatment, there was a tendency to reduce the general intoxication syndrome, shortening of the temperature reaction, duration of coughing. The hyperemia of mucous membrane in oral cavity disappeared with the use of proposed method of treatment on (2.06 \pm 0.05$)$ days earlier than with the traditional one. Duration of catarrhal gingivitis decreased from $(11.01 \pm 0.03)$ to $(9.21 \pm 0.01)$ days, granular enanthema was changed by injection of blood vessels for $(2.06 \pm 0.05)$ in children of the main group and $(3.12 \pm 0.08)$ days in children of the group of comparison. The decrease in the intensity of the enhanced vascular pattern was observed for (7.68 \pm 0.02$)$ days and $(8.06 \pm 0.04)$ days, while the hemorrhagic spots were for $(7.21 \pm 0.01)$ and $(7.68 \pm 0.02)$ days in the children of the main group and comparison group. Erosions on mucous membrane were epithelized with the proposed treatment plan in $(2.89 \pm 0.01)$ days faster, the duration of epithelization of the centers of desquamation of the epithelium of the tongue took $10.68 \pm 0.04$ days (in the comparison group - (12.99 \pm 0.01$)$ days). The intensity of the pain syndrome decreased in $24.41 \%$ of patients. Regression of signs of acute viral sialadenitis were established (an average of 2.32 \pm 0.01 ) days less than that of the patients in the comparison group). The duration of regional lymphadenitis was reduced to $(2.10 \pm 0.01)$ days and amounted to $(11.11 \pm 0.03)$ days.

Conclusion. Monitoring of the effectiveness of the use of herbal licorice root and elecasolum herbal remedies in the complex treatment of children with acute respiratory viral infections with manifestations in oral cavity showed that the use of licorice root solution and elecasolum intraoraly and the local use of drugs in the form of irrigation and appliqués contributes to reducing of the disease duration.

Key words: acute respiratory viral infections; oral lesions; herbal remedies licorice root; children.

ВСтУп. За даними Європейської робочої групи з вивчення грипу, кожний третій житель планети щороку хворіє на гострі респіраторні хвороби. В загальній популяції дитячого населення кількість дітей, які часто хворіють на гострі респіраторні вірусні інфекції (ГРВІ), коливається від 15 до 75 \%. 3-поміж дітей, за даними офріційної статистики, в Україні щороку реєструють 4,5-5 млн випадків захворювання на грип та ГРВІ [1, 2]. Вірусні інсекції, призводячи до розвитку імунопатологічних станів, сприяють виникненню патологічних процесів у багатьох системах організму. Оскільки провідне значення в патогенезі ГРВІ має загальнотоксична, епітеліотропна, вазопатична дія респіраторних вірусів, то ураження слизових оболонок, зокрема слизової оболонки порожнини рота (СОПР), відображають закономірності інсекційного процесу в цілому [3, 4].

Терапію інфекційних захворювань проводять в основному антибактеріальними препаратами, проте використання сучасних фрармакотерапевтичних середників не завжди дозволяє ефективно контролювати інфекційний процес [5, 6]. Інтенсивне зростання захворюваності дітей на ГРВІ та збільшення вартості їх лікування потребують адекватного лікувально-профрілактичного підходу. У зв'язку з цим, в останні роки зріс інтерес до лікарських препаратів рослинного походження, що зумовлено перш за все низькою токсичністю та відносною їх безпечністю, низькою вартістю, це дозволяє рекомендувати їх для широкого симптоматичного і базового (в складі комплексної терапії) лікування гострих респіраторних захворювань [4, $7,8]$. Тому стає зрозумілим підвищений інтерес лікарівстоматологів до фрітопрепаратів, високий профріль безпеки яких добре відомий.

Серед фрітопрепаратів особливе місце по праву займають солодки корінь (Glycyrrhizae radices) та елекасол, обґрунтованість застосування яких підтверджується основними механізмами їх дії - протизапальним, антиоксидантним, протимікробним, стимулювальним, гіпосенсибілізувальним [7, 9-11]. Головною перевагою фрітопрепаратів солодки кореня та елекасолу є оптимальний склад, зумовлений вмістом основної діючої речовини - гліцирризинової кислоти, різноманітних біологічно активних речовин, алкалоїдів, фрлавоноїдів, гліцикумарину, лікокумарину. Препарати гліцирризинової кислоти мають широкий спектр імунологічної дії, яка належить до всіх ланок імунної системи [9].

МЕТА ДОСЛІДЖЕННЯ - оптимізувати схему лікування місцевих проявів захворювання на СОПР у комплексній терапії хворих на ГРВІ дітей шляхом використання фрітопрепаратів солодки кореня та елекасолу.

МАТЕРІАЛИ ТА МЕТОДИ. БУЛо проведено комплексне дослідження та лікування 318 дітей, хворих на ГРВІ, 3 проявами захворювання в порожнині рота 3 використанням клініко-лабораторних методів дослідження. Обстеження пацієнтів полягало в ретельному зборі анамнезу, динамічному клінічному спостереженні, що дало змогу визначати тяжкість захворювання, трива- 
лість загальноінфекційного синдрому, наявність проявів у порожнині рота, втягнення в інфекційний процес слинних залоз, наявність елементів ураження СОПР, термін їх епітелізації. Перелічені клінічні показники враховували при оцінюванні тяжкості перебігу захворювання та есрективності проведеного лікування, що підтверджували лабораторними дослідженнями.

Спостережуваних хворих було поділено на 2 групи: перша включала 127 дітей, у комплексній терапії яких використовували фрітопрепарати солодки кореня та елекасолу для загального і місцевого лікування, друга - 132 пацієнтів, які отримували стандартне лікування згідно з наказами МОЗ України від 19.03.2007 р. № 128 та від 11.11.2009 р. № 813 [12] без застосування препаратів солодки.

Усі хворі отримували базисну терапію з перших днів клінічних проявів респіраторної інфекції. При підвищенні температури тіла, вираженому загальноіноеекційному синдромі призначали жарознижувальні препарати, антигістамінні засоби. Етіотропну терапію хворих проводили противірусними препаратами. Місцево дітям призначали антисептики, анестезувальні засоби, ферменти і, залежно від стадії захворювання, противірусні та кератопластичні засоби.

В основній групі пацієнтів, крім базисної терапії, застосовували фрітопрепарат солодки кореня, при тяжкому перебігу захворювання, зважаючи на надмірне навантаження антибіотикотерапії, призначали комбінований фрітопрепарат із вираженою протимікробною дією - елекасол. Препарати у вигляді відвару чи настою призначали всередину по 1-2 столові ложки за 30 хв до їди 3-4 рази на добу. Місцеве лікування полягало в орошенні порожнини рота відваром та накладанні аплікацій препаратів, які попередньо підігрівали до температури тіла, й обробляли ними СОПР двічі на день. Кількість сеансів визначалась тяжкістю захворювання.

Ефективність запропонованого методу лікування оцінювали в основній та групі порівняння клінічно і лабораторно протягом 3-14 днів від початку захворювання. Клінічний ефект полягав у зменшенні загальноінтоксикаційного синдрому, гострозапальних явищ у порожнині рота.

РЕЗУЛЬТАТИ ДОСЛІДЖЕННЯ ТА ЇХ ОБГОВОРЕННЯ. Результати клінічних досліджень показали, що на фоні застосування препаратів солодки кореня та елекасолу в дітей значно зменшується ступінь вираження загальних симптомів інтоксикації та катаральних явищ зі сторони верхніх дихальних шляхів, слизової оболонки порожнини рота. У пацієнтів, які в комплексному лікуванні отримува- ли фрітопрепарати солодки кореня та елекасолу, відзначали тенденцію до зменшення загальноінтоксикаційного синдрому. Так, скорочення температурної реакції було відмічено у $(70,08 \pm 9,20) \%$ хворих, в яких гарячка закінчувалась за 1-2 дні, тоді як у групі порівняння - лише в $(47,12 \pm 10,1) \%$ випадків $(p<0,05)$. При ускладненні ГРВІ пневмонією частота гарячки протягом 4 днів і більше мала тенденцію до зменшення у хворих основної групи - $(32,28 \pm 1,2) \%$ випадків проти $(43,98 \pm 1,6) \%$ у групі порівняння $(p<0,05)$. Відзначено суттєвий вплив фрітопрепарату на тривалість кашлю. Так, у $(59,84 \pm 1,2) \%$ хворих дітей основної групи кашель проходив за 2-3 доби, тривав 4 доби і більше - в $(14,96 \pm 1,4) \%$, у групі порівняння - продовжувався понад 4 доби в $(52,88 \pm 3,2) \%$ випадків $(\mathrm{p}<0,01)$.

Динамічне спостереження в процесі лікування за дітьми, хворими на грип, парагрип, аденовірусні захворювання, при яких домінували катаральні симптоми, дозволило встановити позитивну динаміку зі сторони зміненої СОПР, яка проявлялася зменшенням гіперемії, набряку, інтенсивності судинного рисунка, геморагій, відторгненням нальоту, вогнищ десквамації епітелію 3 подальшою їх епітелізацією (табл. 1).

Так, виражена гіперемія слизової оболонки порожнини рота тривала 8-10 днів і зникала при запропонованому методі лікування на $(2,06 \pm 0,05)$ дня раніше, ніж при традиційному. Тривалість катарального гінгівіту, який діагностували у 86,79 \% обстежених дітей, становила $(11,01 \pm 0,03)$ дня у групі дітей, які отримували традиційне лікування, та $(9,21 \pm 0,01)$ дня в пацієнтів, яких лікували запропонованим методом.

Зерниста енантема, яка з'являлась у перші 1-2 доби захворювання на фроні яскравої гіперемії м'якого піднебіння, змінювалась ін'єкцією судин упродовж $(2,06 \pm 0,05)$ дня в дітей основної групи та протягом $(3,12 \pm 0,08)$ дня в дітей групи порівняння. Зменшення інтенсивності посиленого судинного рисунка спостерігали протягом $(7,68 \pm 0,02)$ та $(8,06 \pm 0,04)$ дня, а геморагічних плям - $(7,21 \pm 0,01)$ і $(7,68 \pm 0,02)$ дня в дітей основної та групи порівняння відповідно. Ерозії, що утворювались після розкриття міхурцевих висипань на слизовій оболонці порожнини рота, епітелізувались при запропонованій схемі лікування на $(2,89 \pm 0,01)$ дня раніше. Тривалість періоду епітелізації вогнищ десквамації епітелію язика при десквамативному глоситі, який спостерігали в 89,94 \% обстежених дітей, становила у групі порівняння $(12,99 \pm 0,01)$ проти $(10,68 \pm 0,04)$ дня в основній групі. Хейліт, який

\section{Таблиця 1. Тривалість місцевих симптомів захворювання на гострі респіраторні вірусні інфекції в щелепно-лицевій ділянці, порожнині рота дітей при різних методах лікування (дні)}

\begin{tabular}{|c|c|c|c|c|c|c|c|c|c|c|}
\hline \multirow[b]{2}{*}{$\begin{array}{c}\text { Група } \\
\text { обстежених }\end{array}$} & \multicolumn{10}{|c|}{ Симптом } \\
\hline & $\begin{array}{l}\text { лімфра- } \\
\text { деніт }\end{array}$ & хейліт & $\begin{array}{c}\text { ката- } \\
\text { ральний } \\
\text { стоматит }\end{array}$ & гінгівіт & $\begin{array}{c}\text { посилен- } \\
\text { ня судин- } \\
\text { ного } \\
\text { рисунка }\end{array}$ & геморагії & $\begin{array}{l}\text { зерниста } \\
\text { енантема }\end{array}$ & ерозії & $\begin{array}{c}\text { десква- } \\
\text { мативний } \\
\text { глосит }\end{array}$ & $\begin{array}{l}\text { сіала- } \\
\text { деніт }\end{array}$ \\
\hline $\begin{array}{l}\text { Основна група } \\
(\mathrm{n}=127)\end{array}$ & $\begin{array}{l}11,11 \pm \\
0,03 *\end{array}$ & $\begin{array}{l}8,98 \pm \\
0,02 *\end{array}$ & $\begin{array}{l}8,06 \pm \\
0,05 *\end{array}$ & $\begin{array}{l}9,21 \pm \\
0,01 *\end{array}$ & $\begin{array}{l}7,68 \pm \\
0,02 *\end{array}$ & $\begin{array}{l}7,21 \pm \\
0,01 *\end{array}$ & $\begin{array}{l}2,06 \pm \\
0,05 *\end{array}$ & $\begin{array}{l}6,39 \pm \\
0,05 *\end{array}$ & $\begin{array}{l}10,68 \pm \\
0,04 *\end{array}$ & $\begin{array}{l}9,76 \pm \\
0,05 *\end{array}$ \\
\hline $\begin{array}{l}\text { Група порів- } \\
\text { няння }(\mathrm{n}=132)\end{array}$ & $\begin{array}{c}13,21 \pm \\
0,01 *\end{array}$ & $\begin{array}{l}9,68 \pm \\
0,04 *\end{array}$ & $\begin{array}{l}10,12 \pm \\
0,08 *\end{array}$ & $\begin{array}{c}11,01 \pm \\
0,03 *\end{array}$ & $\begin{array}{l}8,06 \pm \\
0,02 *\end{array}$ & $\begin{array}{l}7,68 \pm \\
0,02 *\end{array}$ & $\begin{array}{l}3,12 \pm \\
0,08 *\end{array}$ & $\begin{array}{l}9,28 \pm \\
0,02 *\end{array}$ & $\begin{array}{c}12,99 \pm \\
0,01 *\end{array}$ & $\begin{array}{c}11,23 \pm \\
0,01 *\end{array}$ \\
\hline
\end{tabular}

Примітка. * - всі відмінності достовірні в межах $\mathrm{p}<0,01$. 
діагностували в 16,04 \% випадків, регресував упродовж $(9,68 \pm 0,04)$ дня при загальноприйнятому лікуванні та протягом $(8,98 \pm 0,02)$ дня при запропонованому. При цьому інтенсивність больового синдрому зменшилась у $24,41 \%$ хворих.

При динамічному спостереженні за хворими дітьми в процесі лікування встановлено регресію ознак гострого вірусного сіаладеніту, спричиненого вірусом грипу, - зникали гіперемія, набряк, болючість при пальпації тканин слизової оболонки над залозами. Гострий запальний процес у слинних залозах затихав упродовж 7-9 днів (у середньому на $(2,32 \pm 0,01)$ дня раніше, ніж у хворих групи порівняння), зникав набряк тканин, що оточують слинні залози. Сухість порожнини рота, що виникала, як правило, при середньотяжкій і тяжкій формах гострого вірусного сіаладеніту, зникала протягом 10-12 днів, наставала поступова нормалізація екзокринної фрункції - відновлення салівації, що підтвердилось лабораторно [13].

Критерієм оцінки повноцінного лікування було також скорочення тривалості регіонарного лімфраденіту. На фроні лікування фрітопрепаратами кореня солодки та елекасолу тривалість підщелепового, підборідного лімфаденіту скоротилась на $(2,1 \pm 0,01)$ дня і становила $(11,11 \pm 0,03)$ дня. Переносимість препаратів дітьми раннього та дошкільного віку оцінено як добру. Побічних ефектів при лікуванні уражень органів та тканин порожнини рота не спостерігали.

Отже, застосування фітопрепаратів солодки кореня та елекасолу в комплексному лікуванні хворих на ГРВІ дітей з проявами захворювання в порожнині рота сприяло скороченню тривалості загальноінсекційного синдрому, кашлю, катаральних явищ верхніх дихальних шляхів та слизової оболонки порожнини рота. При оцінюванні ефективності фрітопрепаратів солодки кореня та елекасолу в 127 хворих було виявлено зменшення інтенсивності та скорочення терміну місцевих проявів захворювання в по- рожнині рота (набряку, гіперемії, болю), а також терміну висипань та епітелізації елементів ураження на СОПР.

Таким чином, моніторинг ефективності використання срітопрепаратів солодки кореня та елекасолу в комплексному лікуванні дітей, хворих на ГРВІ, з проявами захворювання в порожнині рота показав, що застосування відвару солодки кореня й елекасолу всередину і місцеве використання препаратів у вигляді орошень та аплікацій приводять до швидкого купірування місцевих проявів на слизовій оболонці порожнини рота.

ВиснОВкИ. 1. Аналіз особливостей перебігу ГРВІ дозволив відмітити, що використання фрітопрепаратів солодки кореня та елекасолу супроводжувалось більш вираженим клінічним ефектом. Обґрунтованість застосування в комплексній терапії фрітопрепаратів солодки кореня та елекасолу підтверджена пригніченням ексудативної, проліферативної фраз запалення органів і тканин порожнини рота, що проявлялося позитивною динамікою зі сторони зміненої СОПР, швидким купіруванням місцевих проявів захворювання. Будучи коректорами метаболічних порушень, препарати підвищують ефективність загальноприйнятої терапії, сприяючи скороченню тривалості захворювання.

2. Використання в комплексній терапії гострих респіраторних вірусних інфекцій у дітей імунокорегувальних препаратів солодки кореня та елекасолу, ряд переваг яких зумовлений вмістом різноманітних біологічно активних речовин, здатних діяти на різних рівнях і етапах патологічного процесу, дозволяє значно підвищити еорективність традиційної терапії та $є$ одним із важливих фракторів їх профрілактики.

ПЕРСПЕКТИВИ ПОДАЛЬШИХ ДОСЛІДЖЕНЬ. ПОдальші дослідження будуть спрямовані на вивчення стану місцевого імунітету порожнини рота, функціональних адаптаційно-компенсаторних реакцій та їх змін у динаміці лікування грипозного стоматиту в дітей.

\section{СПИСОК ЛІТЕРАТУРИ}

1. Проблема інфрекційної захворюваності залишається актуальною проблемою системи охорони здоров'я та держави / О. О. Бобильова, С. П. Бережнов, Л. М. Мухарська [та ін.] // Сучасні інфекції. - 2008. - № 1. - С. 4-10.

2. Крамарєв С. О. Епідемія грипу в Україні / С. О. Крамарєв // Наук.-практ. журн. для педіатрів «3 турботою про дитину». - 2010. - № 1. - С. 9.

3. Боровский Е. В. Заболевания слизистой оболочки полости рта и губ / под ред. Е. В. Боровского, А. Л. Машкилейсона. - М. : МЕДпресс, 2001. - 319 с.

4. Застосування фрітоадаптогенів у стоматології (огляд літератури) / Н. Б. Мірчук, М. С. Драгомирецька, О.В.Дєньга, А. П. Левицький // Вісн. стоматології. - 2007. - № 2. C. $62-66$.

5. Гапонюк П. Я. Профрилактика и лечение гриппа и острых респираторных вирусных инсекций: Гриппсрерон / П. Я. Гапонюк. - М. : МЕДпресс, 2009. - 38 с.

6. Майданник В. Г. Нерациональная антибиотикотерапия и антибиотикорезистентность / В. Г. Майданник // Medicus Amicus. - 2010. - № 5. - C. 23-29.

7. Арыстанова Т. А. Создание лекарственных препаратов на основе компонентов корня солодки и их стандартизации : дис. ... д-ра мед. наук / Арыстанова Т. А. - М., 2010. $308 \mathrm{c}$.

8. Herbal medicines for liver diseases in India / S. Thyagarajan, S. Jayaram, V. Gopalakrishnan [et al.] // J. Gastroenterol. Hepatol. - 2007. - No. 5. - P. 370-376.

9. Изучение иммуномодулирующих свойств препаратов глицирама и густого экстракта солодкового корня / И. А. Муравьев, Л. Е. Старокожко, О. П. Колесникова [и др.] // Хим.-срармац. журн. - 1999. - № 3. - С. 39-41.

10. Югай Н. В. Солодковый корень и возможности его использования в медицине / Н. В. Югай, С. А. Байдурин, Т. П. Арыстанова [и др.] // Астана медициналық журналы. 2009. - № 1. - C. 11-13.

11. Baltina L. Chemical modification of glycyrrizic acid as route to new bioactive compounds for medicine/ L. Baltina // Cum. Med. Chem. - 2007. - Vol. 41. - P. 155-171.

12. Про затвердження Протоколів діагностики та лікування інфекційних хвороб у дітей : наказ МОЗ України від 09.07.2004 p. № 354 .

13. Гевкалюк Н. О. Стан показників гомеостазу ротової рідини при ГРВІ у дітей / Н. О. Гевкалюк // Вісн. наук. дослідж. - 2013. - № 1 (70). - С. 65-68. 


\section{REFERENCES}

1. Bobyliova, O.O., Berezhnov, S.P., \& Mukharska, L.M. (2008). Problema infektsiinoi zakhvoriuvanosti zalyshaietsia aktualnoiu problemoiu okhorony zdorovia ta derzhavy [The problem of infectious morbidity remains an urgent problem of the health care system and the state]. Suchasni infektsii - Modern Infections, 1, 4-10 [in Ukrainian].

2. Kramarev, S.O. (2010). Epidemiia hrypu v Ukraini [Influenza epidemic in Ukraine]. Nauk.-prakt. zhurn. dlia pediatriv "Z turbotoiu pro dytynu" - Scientific and Practical Journal for pediatricians "Care for a child", 1, 9 [in Ukrainian].

3. Borovskiy, E.V., \& Mashkileyson, A.L. (Eds.). (2001). Zabolevaniya slizistoy obolochki polosti rta i gub [Diseases of the mucous membrane of the oral cavity and the lips]. Moscow: MEDpress [in Russian].

4. Mirchuk, B.N., Drahomyretska, M.S., Dienha, O.V., \& Levytskyi, A.P. (2007). Zastosuvannia fitoadaptoheniv u stomatolohii (Ohliad literatury) [Application of phytoadapthogens in dentistry (Review of literature)]. Visnyk stomatolohii - Journal of Dentistry, 2, 62-66 [in Ukrainian].

5. Gaponyuk, P.Ya. Profilaktika i lechenie grippa i ostrykh respiratornykh virusnykh infektsiy [Prevention and treatment of influenza and acute respiratory viral infections]. Moscow: MEDpress [in Russian].

6. Maidannik, V.G. (2010). Neratsionalnaya antibiotikoterapiya i antibiotikoresistentnost [Irrational antibiotic therapy and antibiotic resistance]. Medicus Amicus, 5, 23-29 [in Russian].

7. Aristanova, T.A. (2010). Sozdanie lekarstvennykh preparatov na osnove komponentov kornya solodki i ikh standartizatsii
[Creation of medicinal preparations on the basis of licorice root components and their standardization]. Doctor's thesis [in Russian].

8. Thyagarajan, S., Jayaram, S. \& Gopalakrishnan, V. (2007). Herbal medicines for liver diseases in India. J. Gastroenterol. Hepatol., 5, 370-376.

9. Muravyov, I.A., Starokozhko, L.E., \& Kolesnikova, O.P. (1999). Izuchenie immunomoduliruyushchikh svoystv preparatov glitsirama i gustogo extrakta solodkovogo kornya [The study of immunomodulating properties of glycyrram preparations and a thick extract of licorice root]. Khim.-farmats. zhurn. - Chemical and Pharmaceutical Journal, 3, 39-41 [in Russian].

10. Yugay, N.V., Baydurin, S.A., \& Aristanova, T.P. (2009). Solodkovyy koren i vozmozhnosti ego ispolzovaniya v meditsine [Sweet root and its use in medicine]. Astana meditsinalnyk zhurnaly - Astana Medical Journal, 1, 11-13 [in Russian].

11. Baltina, L. (2007). Chemical modification of glycyrrizic acid as route to new bioactive compounds for medicine. Cum. Med. Chem., 41, 155-171.

12. Pro zatverdzhennia Protokoliv diahnostyky ta likuvannia infektsiinykh khvorob u ditei [On approval of Protocols for diagnosis and treatment of infectious diseases in children]. Nakaz MOZ Ukrainy vid 09.07.2004. №354 [in Ukrainian].

13. Hevkaliuk, N.O. (2013). Stan pokaznykiv homeostazu rotovoi ridyny pry HRVI u ditei [State of indexes of homeostasis of oral liquid with acute respiratory infections in children]. Visn. nauk. Doslidzhen - Journal of Scientific Researches, 1 (70), 65-68. 